International Journal of Instruction

e-ISSN: 1308-1470 • www.e-iji.net

Article submission code

20190910035712

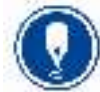

January $2021 \bullet$ Vol.14, No.1

p-ISSN: 1694-609X

pp. 265-282

Received: 10/09/2019

Revision: 18/06/2020
Accepted: 08/07/2020

OnlineFirst: 18/10/2020

\title{
The Effectiveness of Biology Learning-Local Genius Program of Mount Rinjani Area to Improve the Generic Skills
}

\section{Ika Nurani Dewi}

Dr, Biology Education Study Program, UNDIKMA Mataram, Mataram, Indonesia, ikanuranidewi@ikipmataram.ac.id

\section{Septiana Dwi Utami}

Biology Education Study Program, UNDIKMA Mataram, Mataram, Indonesia, septianadwiutami@ikipmataram.ac.id

\section{Ismail Effendi}

Biology Education Study Program, UNDIKMA Mataram, Mataram, Indonesia, ismailefendi_bio@ikipmataram.ac.id

\section{Agus Ramdani}

Dr, Science Education Study Program Post-Graduate School, University of Mataram, Mataram, Indonesia, aramdani07@unram.ac.id

\section{Immy Suci Rohyani}

Dr, Biologi Program Study, University of Mataram, Mataram, Indonesia, immysuci@yahoo.co.id

The study aims at analyzing the effectiveness and practicality of BIL program to improve the generic skills in learning biology. This study was a pre-experimental study with one group pre-test and post-test design on 138 students divided into four groups at several universities in Mataram. The practicality of the program is measured using an observation sheet and effectiveness is measured by an essay test based on a generic skills rubric Data were analyzed using paired t-test, n-gain and ANOVA test. The results showed a significant increase in generic skills, $\mathrm{p}<0.05$, with an average n-gains of 0.09 to 0.53 , and there were differences for the four groups. The practicality results show that the BIL program fulfills the practical requirements with observations of the implementation of learning by $97 \%$ in the good category. Thus, it can be concluded that the BIL program is effective and practical for improving generic skills.

Keywords: effectiveness, practicality, biology learning program, local genius, generic skills

Citation: Dewi, I. N., Utami, S. D., Effendi, I., Ramdani, A., \& Rohyani, I. S. (2021). The Effectiveness of Biology Learning-Local Genius Program of Mount Rinjani Area to Improve The Generic Skills. International Journal of Instruction, 14(1), 265-282. https://doi.org/10.29333/iji.2021.14116a 


\section{INTRODUCTION}

The development of information and communication technology causes changes in the learning process that takes into account the needs of students to develop relevant competencies. The $21 \mathrm{st}$ century takes part in changes in learning that concern to students' needs to develop relevant competencies (Chalkiadaki, 2018; Geisinger, 2016). This shows that there are skills across the field of work that should be mastered by college graduates. Reena (2011) describes skills that cross all fields of scientific disciplines known as generic skills. This definition is in line with that proposed by the National Skill Task Force (Pumphey \& Slater, 2002) that generic skills are skills that cross a number of different jobs. Generic skills can be used as provisions to work in a wider variety of professions both regionally and globally (Urios et al., 2015).

Generic skills are complex intellectual abilities between knowledge and skills (Peśakovič, Flogie \& Aberśek, 2014; Tawil \& Liliasari, 2014; Mulyani, Liliasari, Wiji, Hana \& Nursa'adah, 2016). Quoting from Drury's statement explaining that the knowledge and skills gained by training the generic skills will be relatively longer stored and tend to settle in students' memory (Rosnita, 2016). Generic skills are useful for students in dealing with problems both during lectures and carrying out future work assignments, as well as for adapting to social life. One example is students are able to produce solutions to the problems faced. The description shows the importance of a student to have generic skills as part of 21 st century skills.

The research results of Nastiti, Rahardjo, Susanti \& Perdana (2018) who applied the SSCS model Search, Solve, Create, and Share in the learning process found the influence of the SSCS model on students' generic skills. Fadly, Soegimin \& Poedjiastoeti (2011) argues that students' academic skills will increase through learning that is oriented towards activities of discovery, investigation, and guidance. This view is emphasized by Wahyuni, Amdani \& Harahap (2015) stating that learning programs through a scientific approach are capable of developing student generic skills. However, the applied learning has several weaknesses as follows 1) requiring a learning setting that focuses on the process, and 2) student problem solving activities are not oriented to the community's knowledge and outlook (local genius). The era of globalization has an impact on all aspects of life. The openness of communication, information and social interaction between nations causes changes in character. Reality shifts in character values, resulting in neglected local wisdom values. As we have seen together the knowledge gained by the community in the past can still be developed in the future, so that by using local wisdom in learning can train students' sensitivity to problems in the community

The integration of local wisdom in the biology learning program is an innovation that provides the widest opportunity for students, so that the purpose of learning as a provision to face the globalization era is achieved while still holding fast to the cultural values of the region. Students can successfully live in the future and use local contextual conditions by highlighting local wisdom. Learning using local cultural phenomena as learning media can provide motivational stimuli and help students more easily understand learning (Suardana, Redhana \& Selamet, 2018). In addition, the 
implementation of culture in the curriculum can preserve the uniqueness or culture of the region (Adrian, Badrun \& Hadi, 2018). The Sasak tribe community in the Mount Rinjani area has developed an original system of knowledge and technology as a local wisdom in preserving and managing forests. Local people have the principle of forest management in the form of local knowledge, local intelligence and local policies that are sustainable and actually implemented (Utami, Effendi, Dewi, Ramdani \& Rohyani, 2018). Disclosure of community ideas that are local can be integrated in learning biology, so as to strengthen the meaning of meaningful learning, encourage positive attitudes of students, as well as solve problems faced by wisdom (Dewi et al., 2019).

The results of Utami., et al (2018) showed that most students of IKIP Mataram were less able to explain how to explain their answers well when getting problems that needed explanation and reason. Students have difficulty using knowledge to solve real-life problems. Besides, the students' ability to explain and communicate what is thought still needs to be improved (Dewi et al., 2019). The problem of student thinking skills also occurs when students struggle to find the sequence of genetic information flow process results in the biochemical courses (Zirconia, Supriyanti \& Supriatna, 2018). Reinforced by the research results Cox, Elen \& Steegen (2017) Students have difficulty recognizing the relationship between variables when analogizing abstract concepts. The barriers of creativity often interfere with students ' ability to recognize their creative ideas (Mueler, Melwani, \& Goncalo, 2012). The results of this research indicate low-field skills (generic) students, thus becoming a higher education problem that must resolve immediately. Conditions of low generic student skills if not addressed immediately, will have an impact on the low quality of human resources and a greater effect will hinder the progress of science and technology in Indonesia. The learning step in the BIL Program can revive the values of local wisdom as wealth that must be preserved and realized in everyday life. The BIL program implemented in this study is learning that adapts the values of the local wisdom of the Sasak people in the Mount Rinjani area to improve students' generic skills. The problems that have been described above such as the need for learning settings that bridge the generic skills needed in the 21 st century with local cultural values, are accommodated in the BIL learning program. The development of the BIL program is supported by theories of learning, including constructivist theories, cognitive learning theories, and motivational learning theories (Arends, 2012; Moreno, 2010; Slavin, 2011). The BIL program consists of five stages, namely: 1) exploration, 2) orientation, 3) elaboration, 4) articulation and 5) confirmation (Utami et al., 2018).

The purpose of this study is to analyze the quality of the BIL Program which is determined based on the effectiveness and practicality of the learning program to improve students' generic skills, including indicators according to Brotosiswoyo, namely: symbolic language, developing concepts, logical frames, direct observation, logical inference, modeling, causal law. (Nastiti et al., 2018). The effectiveness of the BIL Program is determined based on a significant (statistically) increase in students' generic skills, an increase in the normalized $\mathrm{N}$-gain score of at least a low criterion, and the consistency of generic skills scores between groups. The practicality of the BIL 
program is determined by observing the results of the learning process in either category.

\section{METHOD}

This study was pre-experimental research using one group pretests and post-test design, namely $\mathrm{O} 1$ x O2 (Fraenkel, Wallen \& Hyun, 2012). The learning process started by providing a pre-test $(\mathrm{O} 1)$ generic skill. After the pre-test, the lecturer applied for BIL program (X) by using learning tool as a form of operational learning program, namely syllabus, semester lesson plan, student activity sheet, and assessment instruments. Learning tools designed by integrating local genius of Mount Rinjani community in Lombok Island include; local traditions, local knowledge, local rules "awiq-awiq", as well as endemic animals and plants in the Mount Rinjani area (Utami et.al. 2018). The learning process ends by giving post-test $(\mathrm{O} 2)$ generic skills. Through the Forum Group Disscucion (FGD) BIL program along with the learning tools have fulfilled the criteria of content validity (needs and state-of-the-art) and constructs validity (Utami et al., 2019).

\section{Population}

This research was conducted on semester 2 students of the 2018/2019 academic year and semester 4 of the 2017/2018 academic year programming ecology and environmental science courses. The selection of samples was based on the Slovin formula, i.e. Sample $=$ [population $/(1+\mathrm{e} 2 \mathrm{x}$ population $)]$ with error tolerance $\mathrm{e}=5 \%$ (Sevilla, Ochave, Punsalan, Regala \& Uriarte, 1984). The samples in this study were 138 students of Undikma and the University of Mataram. The number of samples of Student Biology Education Program of University of Mataram was divided into 2 groups consisting of group 1 (U. 1BE) of fourth semester of Biology education students as many as 40 people, group 2 (U. 2B) of fourth semester Biology students as many as 47 people, while Undikma was divided into group 3 (U. 3BE) of Biology Education program in the second semester as many as 34 people, and group 4 (U. 4BE) of Biology Study Program students in fourth semester as many as 17 people.

\section{Instrument}

The research instrument in the form of an essay test of 7 items referring to the measured generic skills indicator. The practicality of the BIL program is determined based on observations of learning using observation sheets of learning accomplishments and student activities. The instrument has been validated empirically and theoretically by five experts in education and science through Focus Group Discussion (FGD). The assessment components include content, construction and language. The validation results show that the generic skills test instrument and observation sheet of the feasibility of learning in the valid category with the reliability coefficient respectively $90.74 \%$ and $92.95 \%$ in the reliable category (Utami et al., 2019).

\section{Data Analysis}

The generic skill score obtained by calculating the score obtained refers to the generic skill scoring rubric with a score range of 1-4. N-Gain determine by using the equation $\mathrm{n}$ - 
gain $=($ Maximum score - pre-Test Score $) /(4-$ Pre-Test score $)($ Hake, 1999) with criteria: (1) if n-gain $\geq .70$ (height), (2) If. $30<\mathrm{n}$-gain $<.70$ moderate), and (3) if n-gain is $\leq .30$ (Low). Normality scores of students' generic skills for the whole group were carried out by the Kolmogorov-Smirnov test. To know the improvement in the student's generic skills is tested by paired t-test in statistics while the magnitude of the generic skill increase is calculated based on n-gain. The consistency analysis of the generic skill score between groups was tested by using ANOVA test and LSD test. LSD test is conducted to determine differences in generic skills in each group. This test did with the help of IBM SPSS software 17.0. The practicality data of the BIL program was analyzed using the calculation of the average score of the eligibility of each BIL program step by two observers. Eligibility is categorized as good if the average worthiness of each phase is 2.50 with a percentage of $75 \%$ (Borich, 1994).

\section{FINDINGS}

\section{Practicality of BIL Program}

The practicality of the BIL program is determined based on the implementation of learning conducted by lecturers and student activities during learning. The lecturer conducts learning by implementing the BIL Program accompanied by two observers. The results of observations of lecturer and student activities are briefly presented in Table 1.

Table 1

The Observation Results of Lecturer and Student Activities

\begin{tabular}{|c|c|c|c|c|c|c|c|c|}
\hline \multirow[t]{3}{*}{ Learning step } & \multicolumn{4}{|c|}{ Score of Lecturer Performance } & \multicolumn{4}{|c|}{ Score of Student Activity } \\
\hline & \multicolumn{4}{|c|}{ Group } & \multicolumn{4}{|c|}{ Group } \\
\hline & 1 & 2 & 3 & 4 & 1 & 2 & 3 & 4 \\
\hline Eksplorasi & 3.63 & 3.76 & 3.56 & 3.63 & 3.56 & 3.63 & 3.33 & 3.33 \\
\hline Orientasi & 3.00 & 3.00 & 3.10 & 3.20 & 3.20 & 3.20 & 3.10 & 3.00 \\
\hline Elaborasi & 3.20 & 3.00 & 3.20 & 3.00 & 3.30 & 3.35 & 3.05 & 3.05 \\
\hline Artikulasi & 3.50 & 3.10 & 3.30 & 3.00 & 3.20 & 3.20 & 3.10 & 3.00 \\
\hline Konfirmasi & 3.60 & 3.65 & 4.00 & 3.50 & 3.60 & 3.95 & 3.25 & 3.00 \\
\hline Reliability (ICC) & 0.94 & 0.93 & 0.93 & 0.95 & 0.91 & 0.94 & 0.92 & 0.94 \\
\hline Practicality & \multicolumn{4}{|c|}{$91.89 \%$ (very good) } & \multicolumn{4}{|c|}{$90.54 \%$ (very good) } \\
\hline
\end{tabular}

Table 1 explains all the learning steps of the BIL Program that are used can be implemented very well and can be relied upon (fulfilling practical aspects). The learning steps of the BIL Program at each stage amounted to $3.00-3.65$ or the percentage of practicality achieved by $91.89 \%$ in the excellent category. The practicality of the BIL program is also determined based on the activities carried out by students in accordance with the learning steps. Table 5 shows the score of student activity for each learning step of 3.00-3.95 or the percentage of practicality achieved by $90.54 \%$ in the excellent category. Overall, these results indicate that students can follow all the steps of the BIL Program learning well. 


\section{Student generic skills}

After applying for BIL program in the learning process, there was an increase in posttest results generally classified as medium criteria. The mean pre-test and post-test scores, with regards to the generic skills indicator for all groups, are presented in detail in Table 2.

Table 2

The Mean of Pre-test Score, Post-test, and N-gain for Each Indicator of Generic Skills of All Groups

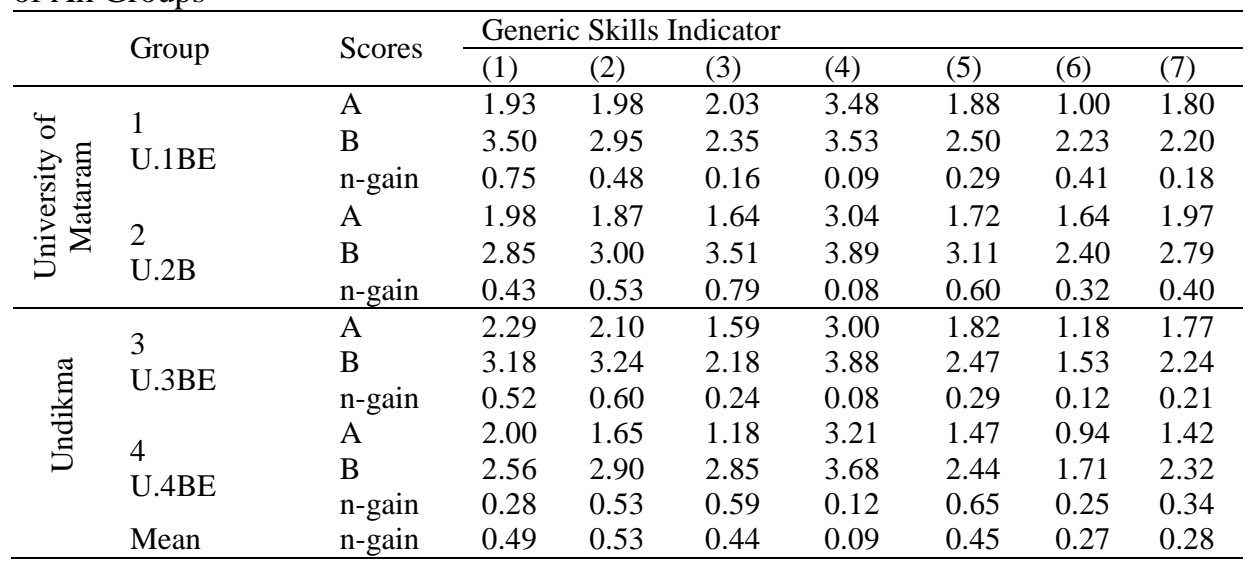

Note: $\mathrm{A}=$ pre-test, $\mathrm{B}=$ post-test, (1) observation direct), (2) observation indirect, (3) symbolic language, (4) logical frame, (5) causal law (6) modeling, (7) developing concepts

Table 2 explains the results of the initial generic skills pre-test of students classified as low, as evidenced by the achievement of a score between 1-2 except in the direct observation indicators the scores obtained above 3. After using the BIL program, there is a generic skill enhancement for any indicator that varies from low and medium categories. The $\mathrm{n}$-gain score in low categories is seen on relevant frame indicators, modeling and developing concepts, each of them amounted $0.09 ; 0.27$; and 0.28 . The $\mathrm{n}$ gain score with medium category obtains on direct observation, indirect observation, symbolic language, and causal law indicators, respectively, $0.49 ; 0.53 ; 0.44$; and 0.45 . Test results for normality and homogeneity of variance indicate that the pre-test, posttest, and n-gain scores of students' generic skills are homogeneous and usually distributed to the whole group. Pre-test and post-test normality scores for all groups were carried out by the Kolmogorov-Smirnov test using IBM SPSS 17.0 software as shown in Table 3. 
Table 3

The Normalized Kolmogorov-Smirnov Test Pre-test and Post-test of Generic Skills

\begin{tabular}{lllllll}
\hline \multirow{2}{*}{ Group } & \multirow{2}{*}{$\mathrm{N}$} & \multirow{2}{*}{ Test } & \multicolumn{6}{l}{ Generic skills } \\
\cline { 3 - 6 } & & & mean & Std. Dev & Asymp. Sig. (2-tailed) & Normal Distrib. \\
\hline \multirow{2}{*}{1} & \multirow{2}{*}{40} & pretest & 51.14 & 10.33 & .500 & Yes \\
& & postest & 68.92 & 12.86 & .838 & Yes \\
2 & \multirow{2}{*}{47} & pretest & 49.64 & 9.10 & .334 & Yes \\
& & postest & 76.97 & 8.74 & .263 & Yes \\
\multirow{2}{*}{3} & \multirow{2}{*}{32} & pretest & 41.79 & 8.44 & .271 & Yes \\
& \multirow{2}{*}{4} & postest & 66.40 & 8.83 & .497 & Yes \\
& \multirow{2}{*}{17} & pretest & 44.73 & 6.92 & .103 & Yes \\
& postest & 66.54 & 15.80 & .343 & Yes \\
\hline
\end{tabular}

Table 3 results of the variance normality test showed that the pre-test and post-test score data obtained through out the group were normally distribution population with $\mathrm{p}>$ 0.05. Therefore, the impact of implementation of BIL program to improve the whole group's generic skills using paired t-test and consistency test is made using the ANOVA test. Test results Paired T-Test and ANOVA as shown in Table 4 and Table 5.

Table 4

Paired-t test Between Pre-test and Post-test Scores for Generic Skills for All Groups

\begin{tabular}{lllllll}
\hline \multirow{2}{*}{ Group } & \multirow{2}{*}{$\mathrm{N}$} & \multicolumn{2}{l}{ Paired t-test, $\alpha=5 \%$} & \multicolumn{2}{l}{ Conclusion } \\
\cline { 3 - 6 } & & Mean & $\mathrm{t}$ & $\mathrm{df}$ & $\mathrm{p}$ & \\
\hline Group 1 & 40 & -17.60 & -8.47 & 39 & .000 & Significantly different \\
Group 2 & 47 & -27.41 & -19.22 & 46 & .000 & Significantly different \\
Group 3 & 34 & -24.28 & -17.35 & 33 & .000 & Significantly different \\
Group 4 & 17 & -21.70 & -6.92 & 16 & .000 & Significantly different \\
\hline
\end{tabular}

Table 4 showed that group 1 (U. 1BE), group 2 (U. 2B), group 3 (U. 3BE) and group 4 (U. 4BE) had a successive degree of freedom (df) respectively of 39, 46, 33, and 16. The $\mathrm{T}$ score for each successive group gives $\mathrm{t}$-value $=-8,472 ; \mathrm{t}=-19.22 ; \mathrm{t}=-17.35 ; \mathrm{t}=-$ 6.92. The score was significant, due to the $\mathrm{p}<0.05$, so there was a significant difference between the pre-test score and the post-test of generic student skills. As a result of negative value calculation, there was a generic skill increase in all groups after the BIL program was applied. 
Table 5

ANOVA Test of Generic Skills in All Groups

\begin{tabular}{lllllll}
\hline Group & ANOVA test $\alpha=5 \%$ & Sum of squares & df & Mean square & F & Sig \\
\hline Group 1 & Between groups & 9021.45 & 1 & .33 & 46.12 & .000 \\
& Within groups & 2151.92 & 54 & .12 & & \\
& Total & 11173.37 & 53 & & & \\
Group 2 & Between groups & 17665.88 & 1 & .88 & 228.94 & .000 \\
& Within groups & 7098.98 & 92 & .16 & & \\
& Total & 24764.87 & 93 & & & \\
Group 3 & Between groups & 10022.54 & 1 & .54 & 191.11 & .000 \\
& Within groups & 3461.29 & 66 & .44 & & \\
& Total & 13483.83 & 67 & & & \\
Group 4 & Between groups & 4006.03 & 1 & .03 & 25.32 & .000 \\
& Within groups & 5061.06 & 32 & .15 & & \\
& Total & 9067.10 & 33 & & & \\
\hline
\end{tabular}

Based on the test result of ANOVA Table 5, it is known that for all groups providing a significant value was .000 or coral of 0.05 . This indicates that there are differences in the students' generic skills improvement after the implemetation of biology learning using the BIL program for all groups. The LSD (Least Significant Different) test was then carried out to find out whether the differences in data of generic skills were stated to be significantly different. The results of LSD test are presented in Table 6 .

Table 6

LSD Test Results of Generic Skills in All Gropus

\begin{tabular}{lllllll}
\hline (I) Group & (J) Group & $\begin{array}{l}\text { Mean difference } \\
\text { (I-J) }\end{array}$ & Std error & Sig & \multicolumn{2}{l}{ Interval } \\
\cline { 6 - 7 } 2 (U.2B) & 3 (U.3BE) & $10.90^{*}$ & 2.50 & .000 & 5.95 & 15.85 \\
& 1 (U.1BE) & $8.22^{*}$ & 2.39 & .001 & 3.49 & 12.95 \\
& 4 (U.4BE) & $10.16^{*}$ & 3.14 & .002 & 3.94 & 16.38 \\
3 (U.3BE) & 2 (U.2B) & $-10.90^{*}$ & 2.50 & .000 & -15.85 & -5.95 \\
& 1 (U.1BE) & -2.67 & 2.59 & .303 & -7.80 & 2.44 \\
& 4 (U.4BE) & -.73 & 3.30 & .824 & -7.26 & 5.79 \\
1 (U.1BE) & 2 (U.2B) & $-8.22^{*}$ & 2.39 & .001 & -12.95 & -3.49 \\
& 3 (U.3BE) & 2.67 & 2.59 & .303 & -2.44 & 7.80 \\
& $4(\mathrm{U} .4 \mathrm{BE})$ & 1.94 & 3.21 & .547 & -4.41 & 8.30 \\
$4(\mathrm{U} .4 \mathrm{BE})$ & 2 (U.2B) & $-10.16^{*}$ & 3.14 & .002 & -16.38 & -3.94 \\
& 3 (U.3BE) & .73 & 3.30 & .824 & -5.79 & 7.26 \\
& 1 (U.1BE) & -1.94 & 3.21 & .547 & -8.30 & 4.41 \\
\hline
\end{tabular}

Table 6 shows the significance value $(\mathrm{p}<0.05)$ between group 2 (U.2B) and group 1 (U.1BE), group 3 (U.3BE), and group 4 (U.4BE). Therefore, it can be stated that generic skills differ significantly in the group after learning to use the BIL program. In other words, the generic skills of students did not differ significantly between group 1 (U.1BE), group 3 (U.3BE), and group 4 (U.4BE) with $(p>0.05)$ at the $5 \%$ significance level. 


\section{DISCUSSION}

The implementation of the BIL program at phase 1 is in a very good category. This phenomenon shows that lecturers prioritize activities by providing meaningful phenomena of motivation and apperception. This activity begins with presenting problems related to the local wisdom of the community to focus the student's attention on the material to be discussed. This statement corresponds to the results of the Seyhan (2014), stating that the presentation of the issue can challenge students to think. The implementation of learning at this stage provides information that lecturers have been able to create a conducive learning environment. This conducive learning environment is seen from the responses that students have given. Students look enthusiastic when given the phenomenon at the beginning of learning to direct the attention and check the fundamental knowledge that the students have.

Another conducive environment is characterized by students' active role in the problemsolving phase of activity. It was intended to ask students to do any problem-solving activity by conducting research activities in small groups. Learning in groups led to the interplay among students and allowed students who were less able to follow the thinking of their more advanced peers (Slavin, 2011). The implementation data of phase 2 shows that the lecturer is capable of presenting student learning needs, so the lecturer can encourage the students to create research problems, and guide in planning the problemsolving process. This effort also comes from the enabling of students sharing with their friends about the knowledge they have in order to solve the problems. It is supported by the mutual relationship theory that students became more active while the learning environment stimulates and encourages their thinking (Moreno, 2010). The students' active becomes a measure of success in resolving the problems little by little, for at that time, according to parkins (Joyce, Weil \& Calhoun, 2009), students practiced gaining and storing knowledge in order to understand concepts and apply the concept in problems solving.

The component of the learning implementation of finding the preconstruction phase through the elaborasi of local wisdom is well implemented. Students become more active in getting concepts if they do it themselves. John Dewey describes learning as an active individual process, not something done for someone, but rather something is done by someone and considers that experiences and inquiries are essential in meaningful learning (Arends, 2012). Other conditions created in this learning are the interaction between students and the interaction between students and lecturers through class discussion in phase 4 . The observation of the discussion activities in communicating the results of problem-solving is in a good category. The improvement is measured by the increasing number of students who make presentations and ask/express opinions to lecturers. Discussions conducted by students in the BIL program enhance their thinking by being open to the views and insights of other students. The interaction is under the theory put forward by Vygotsky, the importance of active student participation through social relations in doing the tasks (Arends, 2012; Jacobsen, Eggen \& Kauchak, 2009).

The implementation data of the process evaluation phase through the konfirmasi of local wisdom shows that lecturers can involve student responsibilities in the evaluation very 
well. This is in line with the opinion of Moreno (2010) That students are involved in assessing the process and the outcome of the study, learning from the process, and implementing what is learned to improve future actions. At this stage, students can evaluate the results that have been obtained, giving confidence and argumentation in resolving the problem. Conducting an evaluation is a decision-making step based on criteria and standards. Further, Brown (Seraphin et al., 2012) explained that learning requires the regulatory ability that involves evaluating what is currently known and determining what still needs to be studied again. Students ' ability to evaluate their work gives confidence to themselves and shows that the activities undertaken by students from start to finish are a meaningful process of learning.

The results of an evaluation of the BIL program stated that the five steps of learning in the program have carried out well in providing a learning environment, which allows students to interact socially with other students and lecturers. The lecturer's involvement in the learning activities in the class for the next cycle is reduced, considering that students are already getting used to the learning steps in the BIL program. Lecturers are also not very involved in practicum activities conducted by students. This is because students get accustomed to implementing the BIL program step. Besides, lecturers have evaluated shortcomings at previous meetings and planning and preparation better at the next meeting. This is in line with the opinion of Fadly et al., (2011), stating that a program of learning is considered practically implemented if the implementation of the model in the process of teaching includes right. In general, BIL program is categorized as a practical program. Based on the description above, the application of the exploration phase, orientation and elaboration of the BIL program is able to strengthen the role of students in developing real-life problem solving, decision making processes and, as well as conducting scientific communication.

A learning program is said to be effective when it is worth measuring the experience and learning outcomes of students, which is seen from the improvement of the students generic skills after the BIL program is implemented. A complete explanation with regards to the effectiveness of BIL program to improve students ' generic skills is outlined as follows: the effectiveness of BIL program is known based on the achievement of students ' generic skills in biology learning shown by Table 1 through Table 6, which are seen from: (1) The increase in pre-test and post-test scores, (2) Score n-gain generic skills of each indicator in a low and medium category, (3) Intergroup interactions that indicate difference. Table 1 shows the mean of pre-test score and the post-test skills of generic students. Low pre-test results show that students are struggling and are not accustomed to implementing generic skills that lecturers have never taught before. This is because the lesson plan designed and applied by teachers does not yet support generic skills learning. Strengthened by Bappena's findings (2014) that some of LPTK in Indonesia are less assured of quality produce competent teachers, so it has not been by design trained in optimal learning.

However, after learning using the BIL program, the overall results for each group of generic skill scores indicated the improvement seen from the post-test score gained. The enhancement (n-gain) skills of generic students are included in low to moderate criteria. 
There are seven well-developed generic skills, namely: (1) Observation direct), (2) Observation indirect, (3) Symbolic language, (4) Logical frame, (5) Causal Law (6) Modeling, (7) Developing concepts. Generic skills enhancement is not separated from the role of learning tools. Consistent with the validation data of the BIL program learning tools include syllabus, semester lesson plan, student activity sheet, and assessment instruments, and valid assessment instruments. (Utami et al., 2019).

Besides BIL program has been specially designed to feature scientific methods (Aydogdu, 2016; Gürses, Çetinkaya \& Dogar 2015). Students are trained to conduct scientific investigative activities in groups through elaboration steps (Phase 3). Group investigations help students learn to do science, solve science issues, and develop thinking skills (Cruz, 2015). This is correlation to the theory of reciprocal relationship model (Moreno, 2010) that students are more actively exploring knowledge when the environment encourages them to think independently. Elaboration steps seek to overcome the weaknesses of previous learning programs (Brickman, Gormally, Hallar \& Armstrong 2009; Fadly et al., 2011; Reena, 2011) in terms of thinking activity emphasized on the activity of scientific discovery by associating local genius as part of science, as well as instruction in exploring the community environment that has not been performed continuously. In line with the Hu \& Adey (2010) hypothesis that group investigations include the activity of asking authentic questions, finding solutions, and science activities. The advantages of elaboration of BIL program in the practicing of generic skills are: 1) Students use the scheme, perform the assimilation process and accommodation to get the truth of the information learned. Assimilation is the process of understanding objects or events based on existing schemes, and accommodation is an attempt to alter existing schemes based on new information or new experience (Slavin, 2011); 2). Flexible thinking, students are given the freedom of producing information, converting mental representations that made into motor activity (Moreno, 2010; Slavin, 2011), as well as 3) scaffolding will instruct students how to solve the problem remains on the right track (Arends, 2012). Based on the description above, the application of the BIL program is able to facilitate students to connect the complexity between biological material and local culture on one side, while preserving the local cultural values of the community on the other side.

The generic skill that develops very well is the skill of conducting direct observation, which is the activity of using the senses in observing the environmental issues surrounding the Mount Rinjani National Park area. During the exploration of the study in the classroom (through video shows), and field practice activities in TNGR forest at Citrus Manis Village, East Lombok, students systematically have gained direct observation skills. The primary purpose of practicum activities is to identify and describe the diversity of organisms as well as macro and microhabitats of TNGR forest ecosystem. Besides, students identified the form of local genius of TNGR forest communities through interviews and observations. The use of more senses during the ecological observation and local genius of TNGR forests makes students able to minister and learn more fun. Haviz, Karomah, Delfita, Umar \& Maris (2018) explained the process of the real approach of natural symptoms could develop the skills of students in doing observations. 
The study also measured indirect observation skills. The opportunity to conduct an observation activity gives students indirectly using measuring instruments as sensing (Tawil \& Liliasari, 2014). In this study, indirect observation skills undertaken by the students observing the abiotic and biotic factors of the TNGR forest area using the community's practicum and ethnoecological tools of the TNGR area using an interview instrument sheet. The interview method provides experience to students as prospective teacher about how to disclose information from the environment as a learning resource. By knowing the concept of biology related to local genius, it hopes that a sense of respect for ancestral culture appears in students. Gondwe \& Longnecker (2014) added that incorporating the cultural knowledge in learning to foster a desire to interact with the environment wisely. The data that has been obtained is then collected to serve as a supporting document for learning. Direct and indirect observation is critical in guiding the process of further learning analysis (Dewi et al., 2019).

According to the Rimatusodic, symbolic language has functions to describe the symbol in science learning (Rosidah, Astuti \& Wulandari, 2017). The symbolic language skills are accomplished by students through the practice of reading, understanding, and designing tables or graphs. Lecturers provide examples as learning materials, to be further studied through group discussions. In this case, each student has different experience and knowledge, so that there is interaction between students or with a more capable person (Arends, 2012; Moreno, 2010). The task of lecturers gives scaffolding if students do not understand the example. Each student internalized in the interaction. Thus symbolic language skill is developed. These findings reinforce the results of the achievement of n-gain symbolic language skills of 0.44 in the medium category. Logical framework indicators are measured based on the student's ability to connect phenomenon with concept. Students are guided to look for logical relationships by conducting analysis of the dynamics of changes in society affecting the environment. Environmental management about local traditions is an active effort that refers to environmental sustainability. These collaborative activities can build students ' logical framework skills. Working collaboratively can build student confidence (Singh \& Gera, 2015). Based on Table 3 analysis, logical framework skills of n-gain scores are still in the low category. This is likely because students are less able to explain the logical relationship between local genius and science content. The explanation given is only limited to the form of local genius.

The skill of causal law was the ability to express a series of relationships between two variables that can be observed and measured (Zirconia et al., 2018). Table 1 indicates the n-gain score of generic skill indicator of the legal cause of the resulting is classified in the medium category of 0.45 . The findings of causal legal skills in this study were assessed based on students ' ability to explain variable-free relationships (local genius forms) with bound variables (environmental issues), estimating causal factors, impacts, and solutions from a variety of study perspectives. The activity stimulates students to have a complete understanding so that students have interrelated thinking. Tsui \& Treagust (2007) reported an analysis of the student's causation ability to influence the early knowledge of functional biology. Student activity in collecting different types of data, recording information, and writing the results of the investigation in the activity 
sheet shows modeling skills. The findings clarify that the student has gained modeling skills with an n-gain score of 0.27 . Difficulties are experienced by students when integrating science content that has the value of the benefits according to the needs of the community and use it to replace old ideas that do not fit the needs or add new ideas based on the value of local genius. The student's difficulties were due to lack of students ' ability to reflect the process simultaneously (Hmelo-Silver \& Azevedo, 2006). Building up a concept is to further develop the idea of an object or process to understand a natural symptom. Concept building skills, as stated in table 4 have an n-gain score of 0.28 or it is is in a low category. This indicates that students are still having trouble integrating knowledge to assimilate new knowledge. It can inhibit the student accommodation process in the structure of cognitive knowledge. Developing new concepts must be compatible with the way of thinking and knowledge that learners already have. In line with the opinion (Kali, Orion \& Eylon 2013; Slavin 2011) process of combining new information at the local knowledge level dissertation by integrating knowledge snippets can build understanding a more robust and unified concept. Table 2 shows that the impact of implementing the BIL program on ecology and environmental knowledge courses was able to improve students' generic skills. The increase in skill scores for all groups is significant and consistent at the 5\% significance level with moderate n-gain. Table 6 is reinforced that there is an impact of the implementation of the BIL program on improving students' generic skills. The magnitude of the impact of the BIL program on increasing generic skills for groups of non-educational students is significantly different at the $5 \%$ level of education students. This is likely due to biology students getting more basic biology material compared to education students. The ratio of biology courses to education courses is $1: 4$, meaning that the number of education courses is 4 times more than biology courses.

Paired t-test results (Table 4) and ANOVA test (Table 5) indicate the implementation of the BIL program has a significant impact on the student's generic skills enhancement. Besides, there is differences of generic skills between groups (Table 6). The understanding of scientific knowledge and generic skills is thoroughly able to create logical thinking to solve problems and develop science. BIL program is a viable alternative to improve the generic skills of students according to the demands of National College Standar. Generic skills allow students to apply and adapt their knowledge to solve problems in new situations faced both in the classroom and outside the classroom or at work (Hadiyanto \& Ibrahim, 2013). Referring to the explanation of Greenstein's (2012), generic skills as a 21st-century skill includes problem-solving skills, analysis, and decision making (Rozlin et al., 2018). The explanation above indicates that generic skills make it easier for students to carry out science experiments, build concepts in scientific activities, and solve various problems in order to be successful in learning.

BIL program is an innovative and original work, which is a learning process that emphasizes the integrated research activities of local genius so that students understand the concept while having generic skills. Description of program effectiveness data tested to overcome higher education problems in Indonesia, unusually low generic skills. The repetition of a generic skill training at each meeting is crucial for the internalization 
process. According to the retention theory, students must do repetition so that the procedural knowledge owned can be remembered (Moreno, 2010). The implementation of the BIL program is able to prepare the students successfully live in the future, namely students: 1) being able to apply the concepts and principles of science-pedagogical biology and biology to conduct planning, management, implementation, Evaluation by utilizing science and technology, 2) having learning skills and innovation, 3) being able to utilize the natural resources of environmentally sound. Students prepared for success in their future work and career (Hadiyanto \& Ibrahim, 2013; Sitti, Sooperak \& Sompong 2013; Yaacob, 2011). The development of generic skills is integrated with the potential of local genius in the learning process in the classroom, preferably familiarized and practiced for an extended period so that the results can be utilized to overcome real-life problems. This research is still limited to the potential of local wisdom used in this study is limited to the area of the Mount Rinjani National Park. Learning can not feel without constraints, the most essential thing for lecturers is able to maximize the role of students ' responsibilities in overcoming the barriers to development of scientific work skills in him to support success in the teaching process itself, besides the lecturer must arrange the learning that connects between knowledge with generic skills (Hadiyanto \& Ibrahim, 2013). Therefore, the fundamental implication of this research is that the main alternative of the BIL program is that it can be widely applied in the world of education in Indonesia so that the golden generation that is able to innovate is no longer merely a dream.

\section{CONCLUSIONS}

The BIL program is included in the effective category, in terms of a significant increase in generic skills at $\mathrm{p}<0.05$, with an average n-gain of 0.09 to 0.53 , and there are differences for the four groups. The practicality results show that the BIL program fulfills the practical requirements with observations of the implementation of learning by 97\% in either category. Thus, it can be concluded that the BIL program is effective and practical for improving generic skills. The BIL program is an innovative solution that can be widely applied in the Indonesian education world as an alternative learning program to improve students' generic skills and internalize local culture as a source of learning.

\section{ACKNOWLEDGMENTS}

Our acknowledgments convey to the Ministry of Research and Technology of DIKTI for research assistance through the Research Grant of Higher Education Cooperation (SK Number: 01/K8.0572/L1/SK/IKIP-Mtr/2018). We would like to say thanks to the rector of IKIP Mataram and the University of Mataram and their staff who have provided support and facilities during the research process, as well as to all those that helped to research and writing of this article can be completed properly.

\section{REFERENCES}

Adrian, D., Badrun, K., \& Hadi, S. (2018). The instrument development to evaluate local curriculum in Indonesia. International Journal of Instruction, 11(4), 921-934. doi:10.12973/iji.2018.11458a. 
Arends, R. I. (2012). Learning to teach. New York: Mc. Graw-Hill Companies.

Aydogdu, B. (2016). The investigation of science process skills of Science teachers in term of some variables. Educational Research and Reviews, 10(5), 582-594.

Bappenas. (2014). Rancangan awal rencana pembangunan jangka menengah nasional 2015-2019: Buku II agenda pembangunan bidang. Jakarta: Kementerian Perencanaan Pembangunan Nasional/Badan Perencanaan Pembangunan Nasional.

Borich, G. D. (1994). Observation skills for effective teaching. Englewood Cliffs: Merrill Publisher.

Brickman, P., Gormally, C., Hallar, B., \& Armstrong, N. (2009). Effect of inquiry based learning on students science literacy skill and confidence. International Journal for Scholarship of Teaching and Learning, 3(2), 1-22. https://doi.org/10.20429/ijsotl.2009.030216.

Chalkiadaki, A. (2018). A systematic literature review of $21^{\text {st }}$ century skills and competencies primary education. International Journal of Instruction, 11(3), 1-16. doi:10.12973/iji.2018.1131a.

Cox, M., Elen, J., \& Steegen, A. (2017). System thinking in geography: Cam high school students do it? International Research in Geographical and Environmental Education, 28(1), 37-52. https://doi.org/10.1080/10382046.2017.1386413.

Cruz, J. P. C. D. (2015). Development of an experimental science module to improve middle school students' integrated science process skills. Proceedings of the DLSU Research Congress, 3, 1-6.

Dewi, I. N., Ibrahim, M., Poedjiastoeti, S., Prahani, B. K., Setiawan, D., \& Sumarjan. (2019). Effectiveness of local genius integrated (LWI) learning model to improve scientifiec communications skills of junior high school students in science learning. Journal of Physics: Conf Series, 1157, 022014. doi:101088/1742-6596/1157/2/022014.

Fadly, W., Soegimin, W, W., \& Poedjiastoeti, S. (2011). Pengembangan program pembelajaran praktikum fisika dasar berorientasi heuristic terbimbing untuk meningkatkan kecakapan akademik mahasiswa. Jurnal Penelitian Pendidikan Sains, 1(1), 36-43. https://journal.unesa.ac.id/index.php/jpps/article/view/389.

Fraenkel, J. R., Wallen, N. E., \& Hyun, H. (2012) How to design and evaluate research in education. New York: Mc. Graw-Hill Companies.

Geisinger, K. F. (2016). 21st century skills: What are they and how do we assess them? Journal Applied Measurement in Education, 29(4), 245-249. doi.org/10.1080/08957347.2016.120927.

Gondwe, N., \& Longnecker, N. (2014). Scientific and cultural knowledge in intercultural science education: student perceptions of Common ground. Research Science Education, 45(1), 1-31. doi:10.1007/s11165-014-9416-z. 
Greenstein, L. (2012). Assessing 21st century skills. A guide evaluating mastery and authentic learning. The United States of America: Corwin a Sage Company.

Gürses, A., Çetinkaya, S., \& Dogar, C. (2015). Determination of levels of use of basic process skills of high school students. Procedia - Social and Behavioral Sciences, 191, 644 - 650. doi: 10.1016/j.sbspro.2015.04.243.

Hadiyanto., \& Ibrahim, S. M. (2013). Students' generic skills at the National University of Malaysia and the National University of Indonesia. Procedia Social and Behavioral Sciences, 83, 71-82. doi: 10. 1016/j.sbspro.2013.06.015.

Hake, R. R. (1999). Interactive-engagement versus traditional methods: A six-thousandstudent survey of mechanics test data for introductory physics courses. American Journal of Physics, 66(1), 64-74. https://doi.org/10.119/1.18809.

Haviz, M., Karomah, H., Delfita, R., Umar, M. I. A., \& Maris, M. (2018). Revisiting generic Science skills as 21 st century skills on biology learning. Jurnal Pendidikan IPA Indonesia, 7(3), 355-363. https://doi.org/10.15294/jpii.v7i3.12438.

Hmelo-Silver, C. E., \& Azevedo, R. (2006). Understanding complex systems: Some cor challenges. The Journal of The Learning Sciences, 15(1), 53-61. https://doi.org/101207/s15327809jls1501_7.

Hu, W., \& Adey, P. (2010). A scientific creativity test for secondary school students. International Journal of Science Education, 24(4), 389-403. https://doi.org/10.1080/09500690110098912.

Jacobsen, D. A., Eggen, P., \& Kauchak, D. (2009). Methods teaching: Promoting student learning in K-12 classrooms. USA: Pearson Education Inc.

Joyce, B., Weil, M., \& Calhoun, E. (2009). Models of teaching. USA: Pearson Education Inc.

Kali, Y., Orion, N., \& Eylon, B. S. (2013). Effect of knowledge integrative activities on students' perception of the earth's crust as a cyclic System. Journal of Research in Science Teaching, 40(6), 545-565. https://doi.org/10.1002/tea.10096.

Moreno, R. (2010). Educational psychology. New Mexico: John Wiley \& Sons, Inc.

Mueller, J. S., Melwani, S., \& Goncalo, J. A. (2012). The bias against creativity: Why people desire but reject creative ideas. Psychological Science, 23(1), 13-17. https://doi.org/10.1177/0956797611421018.

Mulyani, S., Liliasari., Wiji., Hana, M. N., \& Nursa'adah, E. (2016). Improving students's generic skill in Science through chemistry learning pushing ICT-based media on reaction rate and osmotic pressure material. Jurnal Pendidikan IPA Indonesia, 5(1), 150-156. doi: 10.15294/jpii.v5i1.5804.

Nastiti, D., Rahardjo, S. B., Susanti, E., \& Perdana, R. (2018). The need analysis of modul Development based on search, solvent, create, and share to increase generic 
Science skills in chemistry. Jurnal Pendidikan IPA Indonesia. 7(4), 428-434. https://doi.org/10.15294/jpii.v7i4.12393.

Peśakovič, D., Flogie, A., \& Aberśek, B. (2014). Development and evaluation of a competence-based teaching process for science and technology education. Journal of Baltic Science Education, 13(5), 740-755.

Pumphey, J., \& Slater, J. (2002). An assessment of generic skill needs. Nottingham: Department for Educations and Skills.

Reena, G. (2011). Fostering generic skills through participatory learning strategies. International Journal of Fundamental Psychology and Social Science, 1(1), 14-16. http://www.sciepub.com/reference/113225.

Rosidah, T., Astuti, P, A., \& Wulandari, A. V. (2017). Eksplorasi keterampilan generik sains mahasiswa pada mata pelajaran kimia di SMAN 9 Semarang. Jurnal Pendidikan Sains, 5(2), 130-137. https://doi.org/10.26714/jps.5.2.2017.130-137.

Rosnita. (2016). The Development of laboratory-based earth and space Science learning model to improve Science generic skills of pre-service teachers. Jurnal Pendidikan IPA Indonesia, 5(2), 171-176. https://doi.org/10.15294/jpii.v5i2.7677.

Rozlin, R., Ismail, F., Idris, N., Mustaffa, N. E., Saat, M. M., Jamal, M. N., \& Ramakrishnan. (2018). Generic skills of the undergraduates: A Case Study of faculty of built Environment in Universiti Teknologi Malaysia. International Journal of Engineering \& Technology. 7(2.29). 297-302. doi:10.14419/jet.v7i2.29.13642.

Seraphin., Kanesa D., Philippoff., Joanna., Kaupp., Lauren., Valli., \& Lisa, M. (2012) Metacognition as means to increase the effectiveness of inquiry-based science

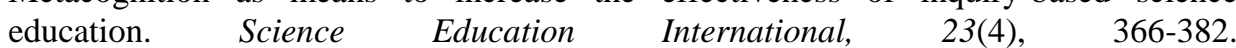
https://eric.ed.gov/?id=EJ1001630.

Sevilla, C. G., Ochave, J. A., Punsalan, T. G., Regala, B. P., \& Uriarte, G. G. (1984). An introduction to research methods. Quezon City: Rex Printing Company.

Seyhan, G. H. (2014). The investigation of the perception of problem solving skills by pre-service science teachers in the science laboratory. Eurasian Journal of Physics and Chmeristry Education, 6(2), 142-161.

Singh, H., \& Gera, M. (2015). Developing generic skills in higher education. Indian Journal of Applied Research, 5(6), 823-826. https://doi.org/10.36106/ijar.

Sitti, S., Sooperak, S., \& Sompong, N. (2013). Development of instructional model based on connectives learning theory to enhance problem-solving skill in ICT for daily life of higher education students. Procedia Social and Behavioral Sciences, 103, 315322.doi: 10.1016/j.sbspro.2013.10.339.

Slavin, R. E. (2011). Educational psychology, theory and practice. Boston: Pearson Education Inc. 
Suardana, I, N., Redhana, I. W., \& Selamet, I. Y. (2018). Students critical thinking skills in chemistry learning use local culture based 7E learning cycle model. International Journal of Instruction, 11(2), 399-412. https://doi.org/10.12973/iji.2018.11227a.

Tawil, M., \& Liliasari. (2014). Keterampilan-keterampilan sains \& implementasinya dalam pembelajaran IPA. Makasar: Universitas Negeri Makasar.

Tsui, C. Y., \& Treagust, D. F. (2007). Understanding genetics: Analysis of secondary students' conceptual status. Journal of Research in Science Teaching, 44(2), 205-235. https://doi.org/10.1002/tea.20116.

Urios, I, M., Rangel, R, E., Tomas, B, R., Salvador, T, J., Garcia, C, F., \& Piquer, F, C. (2015). Generic skill development and learning/assessment process: use of rubrics and student validation. Journal of Technology and Science Education, 5(2), 107-121. http://dx.doi.org/10.3926/jotse.147.

Utami, S. D., Effendi, I., Dewi, I. N., Ramdani, A., \& Rohyani, I. (2018). the study of local genius of ethnic sasaks in development of biology instructional learning program (P3Bio) based on 21st century skills. Advances in Intelligent Systems Research (AISR), 157. https://www.atlantis-press.com/proceedings/miseic-18.

Utami, S. D., Effendi, I., Dewi, I. N., Ramdani, A., \& Rohyani, I. (2018). Buku panduan program pembelajaran biologi terintegrasi kearifan lokal. Mataram: Duta Pustaka Ilmu.

Utami, S. D., Effendi, I., Dewi, I. N., Ramdani, A., \& Rohyani, I. (2019). Validitas perangkat pembelajaran etnoekologi masyarakat Suku Sasak kawasan taman nasional Gunung Rinjani. Jurnal Penelitian Pendidikan IPA, 5(2), 240-247. https://doi.org/10.29303/jppipa.v5i2.291.

Wahyuni, I., Amdani, K., \& Harahap, H, M. (2015). Pengembangan program pembelajaran berbasis pendekatan pembelajaran saintifik untuk meningkatkan keterampilan generik sains calon guru fisika. Jurnal Inovasi Pembelajaran Fisika, 3(2), 29-42. https://doi.org/10.24114/inpafi.v3i2.4227

Yaacob, M. (2012). Integrating generic competencies (GCs) into University's compulsory courses: perspectives of lectures and students. Procedia Social and Behavioral Sciences, 59, 574-583. https://doi.org/10.1016/j.sbspro.2012.09.316.

Zirconia, A., Supriyanti, F. M. T., \& Supriatna, A. (2018). Generic science skills enhancement of students through implementation of ideal problem solving model on genetic information course. Journal of Physics: Conf. Series: Materials Science and Engineering, 349. https://doi.org/10.1088/1757-899X/349/1/012008. 